\title{
PRODUCTION AND PROPERTIES OF $\alpha$-AMYLASE FROM THERMOPHILIC BACILLUS SP.
}

\author{
Carlos Alberto Martins Cordeiro; Meire Lelis Leal Martins*; Angélica Bárbara Luciano \\ Centro de Ciências e Tecnologias Agropecuárias, Universidade Estadual do Norte Fluminense, \\ Campos dos Goytacazes, RJ, Brasil
}

Submitted: March 02, 2001; Returned to authors for corrections: June 25, 2001; Approved: February 25, 2002

\begin{abstract}
$\alpha$-amylase (1,4- $\alpha$-D-glucan glucanohydrolase, EC 3.2.1.1) production by thermophilic Bacillus sp strain SMIA-2 cultivated in liquid media containing soluble starch reached a maximum at 48h, with levels of 57U/ $\mathrm{mL}$. Studies on the $\alpha$-amylase characterization revealed that the optimum temperature for activity was $70^{\circ} \mathrm{C}$. The enzyme was stable for $2 \mathrm{~h}$ at $50^{\circ} \mathrm{C}$, while at $60^{\circ} \mathrm{C}, 70^{\circ} \mathrm{C}$ and $90^{\circ} \mathrm{C}, 4 \%, 13 \%$ and $38 \%$ of the original activities were lost, respectively. The optimum $\mathrm{pH}$ of the enzyme was 7.5. After incubation of crude enzyme solution for $24 \mathrm{~h}$ at $\mathrm{pH} 7.5$, a decrease of about $5 \%$ of its original activity was observed. The enzyme was strongly inhibited by $\mathrm{Co}^{2+}, \mathrm{Cu}^{2+}$ and $\mathrm{Ba}^{2+}$, but less affected by $\mathrm{Ca}^{2+}, \mathrm{Mg}^{2+}, \mathrm{Ni}^{2+}, \mathrm{Sr}^{2+}$ and $\mathrm{Mn}^{2+}$. The enzyme in $1 \mathrm{M}$ and $5 \mathrm{M} \mathrm{NaCl}$ solutions the enzyme retained $70 \%$ and $47 \%$ of the original activity after $24 \mathrm{~h}$ of incubation at $4^{\circ} \mathrm{C}$, respectively.
\end{abstract}

Key-words: $\alpha$-amylase, thermophilic bacterium, Bacillus sp.

\section{INTRODUCTION}

Thermophilic and extremely thermophilic microorganisms have gained a great deal of attention recently $(2,3,11,21)$. Enzymes from these microorganisms are of special interest since they are not usually denatured by high temperatures and are even active at elevated temperatures $(1,6,10,23,24)$. The genus Bacillus produces a large variety of extracellular enzymes, some of which such as the amylases are of significant industrial importance (4). Among these enzymes, the thermostable varieties are more versatile with respect to industrial significance. Thermostable $\alpha$-amylases have had many commercial applications for several decades. These enzymes are used in the textile and paper industries, food, adhesive, and sugar production $(12,15,16,18,21,22)$.

The $\alpha$-amylases produced by different Bacillus species vary not only in their types (saccharifying or liquefying) but also in the range of $\mathrm{pH}$ and temperature for their optimal activity. The bacterial source of the enzyme is usually from either Bacillus amyloliquefaciens or Bacillus licheniformis, the latter now being of greater industrial importance (5).
In this article the production of thermostable $\alpha$-amylase by thermophilic Bacillus sp strain SMIA-2, previously isolated from a soil sample collected in Campos dos Goytacazes City, Rio de Janeiro, Brazil, is reported.

\section{MATERIALS AND METHODS}

\section{Organism}

The bacterial strain used in this study was a thermophilic Bacillus sp strain SMIA-2 (19), previously isolated from a soil sample collected in Campos dos Goytacazes City, Rio de Janeiro, Brazil. Phylogenetic analysis showed that this strain is a member of the Bacillus rRNA group 5. This group includes Bacillus stearothermophilus and other thermophilic Bacillus spp. The optimum temperature and $\mathrm{pH}$ for growth of this organism were around $55^{\circ} \mathrm{C}$ and $\mathrm{pH} 7.0$, respectively. The organism was found to produce $\alpha$-amylase on culture medium composed of $1 \%$ Soluble starch, $0.2 \%$ Yeast extract, $0.5 \%$ Peptone, $0.05 \% \mathrm{MgSO}_{4}, 0.05 \% \mathrm{NaCl}, 0.015 \% \mathrm{CaCl}_{2}$ and $2 \%$ agar at $55^{\circ} \mathrm{C}(\mathrm{pH} 7.0)$.

\footnotetext{
* Corresponding author. Mailing address: Centro de Ciências e Tecnologias Agropecuárias, Universidade Estadual do Norte Fluminense. Av. Alberto Lamego, 2000. 28015-620, Campos dos Goytacazes, RJ, Brasil. Phone: (+5522) 726 3880, Fax: (+5522) 7263875.
} 


\section{Enzyme production}

The culture medium used in this work for $\alpha$-amylase production contained (g/L): $\mathrm{NaH}_{2} \mathrm{PO}_{4} .2 \mathrm{H}_{2} \mathrm{O}-1.56, \mathrm{NH}_{4} \mathrm{Cl}-5.35$, $\mathrm{KCl}-0.745, \mathrm{Na}_{2} \mathrm{SO}_{4} \cdot 10 \mathrm{H}_{2} \mathrm{O}-0.644$, Citric acid- $0.42, \mathrm{MgCl}_{2} \cdot 6 \mathrm{H}_{2} \mathrm{O}-$ $0.25, \mathrm{CaCl}_{2}-2.2 \times 10^{-3}, \mathrm{ZnO}-2.5 \times 10^{-3}, \mathrm{FeCl}_{3} .6 \mathrm{H}_{2} \mathrm{O}-2.7 \times 10^{-2}$, $\mathrm{MnCl}_{2} .4 \mathrm{H}_{2} \mathrm{O}-1.0 \times 10^{-2}, \mathrm{CuCl}_{2} .2 \mathrm{H}_{2} \mathrm{O}-8.5 \times 10^{-4}, \mathrm{CoCl}_{2} \cdot 6 \mathrm{H}_{2} \mathrm{O}-2.4 \times 10^{-3}$, $\mathrm{NiCl}_{3} .6 \mathrm{H}_{2} \mathrm{O}-2.5 \times 10^{-4}, \mathrm{H}_{3} \mathrm{BO}_{3}-3.0 \times 10^{-4}, \mathrm{Na}_{2} \mathrm{MoO}_{4}-1.0 \times 10^{-3}$, Bactotryptone-10.0, Yeast extract-2.5 and Soluble starch-5. The $\mathrm{pH}$ was adjusted to 6.9-7.0 with $1.0 \mathrm{M} \mathrm{NaOH}$ and this basal medium was sterilised by autoclaving at $121^{\circ} \mathrm{C}$ for $15 \mathrm{~min}$. Yeast extract, Bacto-tryptone and Soluble starch were sterilised separately and aseptically added to the flasks containing the liquid medium, after cooling. The above medium $(50 \mathrm{~mL}$ in $250 \mathrm{~mL}$ Erlenmeyer flasks) was inoculated with $1 \mathrm{~mL}$ of an overnight culture and incubated at $55^{\circ} \mathrm{C}$ with vigorous aeration in a rotary shaker at $150 \mathrm{rpm}$ for $144 \mathrm{~h}$. At time intervals, the turbidity of the cultures was determined by measuring the optical density at $470 \mathrm{~nm}$ in a Hitachi Model U-2000 spectrophotometer. Before assay, the cells were separed by centrifugation at $13.000 \mathrm{rpm}$ for $15 \mathrm{~min}$ and the clear supernatant was used as crude enzyme preparation.

\section{Amylase Assay}

The activity of $\alpha$-amylase was assayed by incubating 0.3 $\mathrm{mL}$ enzyme with $0.5 \mathrm{~mL}$ Soluble starch $(1 \%, \mathrm{w} / \mathrm{v})$ prepared in $0.05 \mathrm{M}$ Phosphate buffer, $\mathrm{pH} 6.5$. After incubation at $90^{\circ} \mathrm{C}$ for 10 min the reaction was stopped and the reducing sugars released were assayed colorimetrically by the addition of $1 \mathrm{~mL}$ of 3-5dinitrosalicylic acid reagent (17). An enzyme unit is defined as the amount of enzyme releasing $1 \mathrm{mmole}$ of glucose from the substrate in $1 \mathrm{~min}$ at $90^{\circ} \mathrm{C}$.

\section{Effect of pH on activity and stability of $\alpha$-amylase}

Effect of $\mathrm{pH}$ on the activity of $\alpha$-amylase was measured by incubating $0.3 \mathrm{~mL}$ of enzyme and $0.5 \mathrm{~mL}$ of buffers, adjusted to $\mathrm{pH}$ of 5.5 to 8.5, containing Soluble starch $(0.5 \%)$. The buffers used were: sodium acetate $\mathrm{pH} 5.5$; phosphate $\mathrm{pH} 6.0-8.0$; Tris- $\mathrm{HCl} \mathrm{pH}$ 8.5. Stability of the enzyme at different $\mathrm{pH}$ values was also studied by incubating the enzyme at various $\mathrm{pH}$ values ranging from $5.5-8.5$ for $24 \mathrm{~h}$ and then estimating the residual activity.

\section{Effect of temperature on activity and stability of $\alpha$-amylase}

The effect of temperature on the enzyme activity was determined by performing the standard assay procedure as mentioned earlier for $10 \mathrm{~min}$ at $\mathrm{pH} 6.5$ within a temperature range of $40-100^{\circ} \mathrm{C}$. Thermostability was determined by incubation of crude enzyme at temperatures ranging from $40-100^{\circ} \mathrm{C}$ for $2 \mathrm{~h}$ in a constant-temperature water bath . After treatment the residual enzyme activities were assayed.

\section{Effect of metal ions}

The effect of different metal ions on $\alpha$-amylase activity was determined by the addition of the corresponding ion at a final concentration of $1 \mathrm{mM}$ to the reaction mixture, and assayed under standard conditions. The enzyme assay was carried out in the presence of $\mathrm{Ca}^{2+}, \mathrm{Mg}^{2+}, \mathrm{Fe}^{2+}, \mathrm{Fe}^{3+}, \mathrm{Co}^{2+}, \mathrm{Zn}^{2+}, \mathrm{Mn}^{2+}, \mathrm{Hg}^{2+}$, $\mathrm{Cu}^{2+}, \mathrm{Cs}^{2+}, \mathrm{Ni}^{2+}, \mathrm{Sr}^{2+}, \mathrm{Ba}^{2+}, \mathrm{Ag}^{1+}$ chlorides, $\mathrm{Pb}^{2+}$ acetate, and $\mathrm{Cu}^{2+}$ sulphate.

\section{Salt tolerance test}

Enzyme was incubated in $10 \mathrm{mM}$ Phosphate buffer ( $\mathrm{pH}$ 7.0) containing various $\mathrm{NaCl}$ concentrations $(0.05$ to $5 \mathrm{M})$ for $24 \mathrm{~h}$ at $4^{\circ} \mathrm{C}$ and in each case activity of the enzyme was measured in the same way as mentioned earlier.

\section{RESULTS AND DISCUSSION}

\section{Enzymatic production}

Fig. 1 reports the time-course of $\alpha$-amylase production by Bacillus sp. strain SMIA-2 grown in basal medium supplemented with $0.5 \%$ Soluble starch. $\alpha$-amylase production reached a maximum at $48 \mathrm{~h}$, with levels of $57 \mathrm{U} / \mathrm{mL}$. Subsequently, $\alpha$-amylase levels remained more or less constant up to $96 \mathrm{~h}$ and after $144 \mathrm{~h}$ $\mathrm{n}$ dropped to $23 \mathrm{U} / \mathrm{mL}$. It was observed that maximum $\alpha$-amylase production occurred when the cell population reached the peak, suggesting that this organism may be unusually sensitive to metabolite repression. Effective induction may not occur until the stationary phase has been reached and the readily available carbon source was depleted.

\section{Effect of pH on activity and stability of $\alpha$-amylase}

The effect of $\mathrm{pH}$ on $\alpha$-amylase activity is shown in Fig.2. Optimum $\mathrm{pH}$ was found to be 7.5. The enzyme activity at $\mathrm{pH} 5.5$ and 10.0 were $73 \%$ and $55 \%$ of that at $\mathrm{pH} 7.5$, respectively. After incubation of crude enzyme solution for $24 \mathrm{~h}$ at $\mathrm{pH} 5.0-10$, a decrease of about $5 \%$ of its original activity at $\mathrm{pH} 7.5$ was

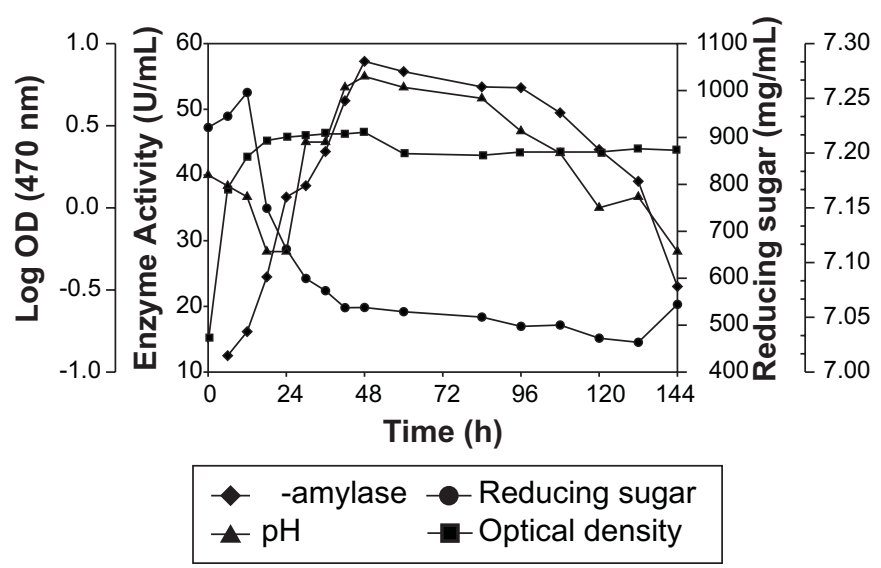

Figure 1. Time course of $\alpha$-amylase production by Bacillus sp. strain SMIA-2 grown at $55^{\circ} \mathrm{C}$ on $0.5 \%$ soluble starch in shake flasks. 


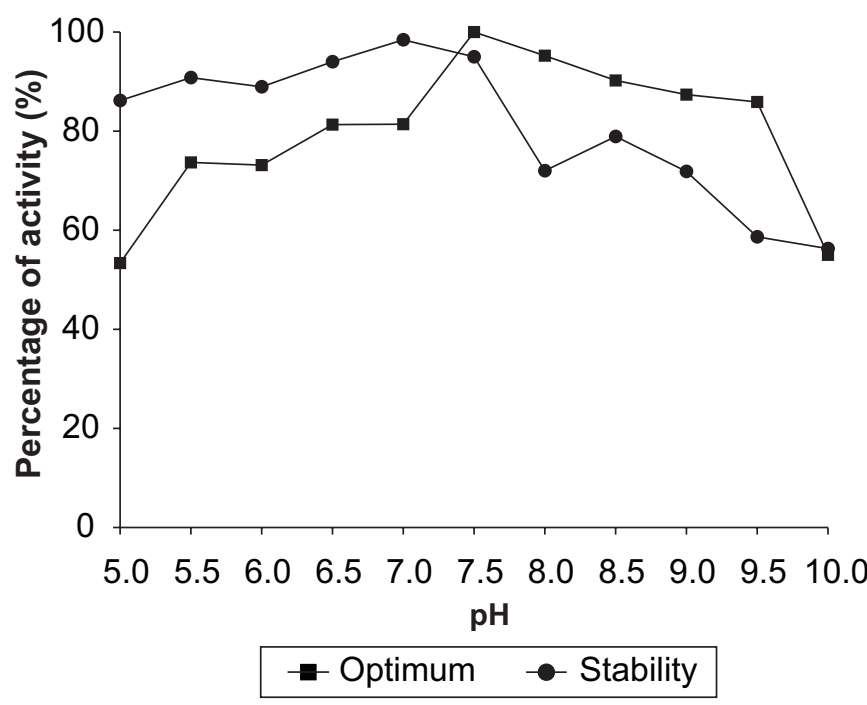

Figure 2. Optimum $\mathrm{pH}$ and stability $\mathrm{pH}$ of $\alpha$-amylase produced by Bacillus sp. strain SMIA-2 grown at $55^{\circ} \mathrm{C}$ for $48 \mathrm{~h}$. Relative activity is expressed as a percentage of the maximum (100\% of enzyme activity $=92 \mathrm{U} / \mathrm{mL}$ ).

observed. At pH 10.0, the decrease was of $44 \%$. Thus, $\alpha$-amylase of Bacillus sp. strain SMIA-2 strain seems to be active in very broad $\mathrm{pH}$ range.

\section{Effect of temperature on activity and stability of $\alpha$-amylase}

The supernatant amylolytic activity were assayed at different temperatures ranging from $40^{\circ} \mathrm{C}-100^{\circ} \mathrm{C}$ at a constant $\mathrm{pH}$ of 7.5 and a substrate concentration of $0.5 \%$ as shown in Fig. 3. Enzyme activity increased with temperature within the range of $40^{\circ} \mathrm{C}$ to $70^{\circ} \mathrm{C}$. A reduction in enzyme activity was observed at values above $70^{\circ} \mathrm{C}$. The optimum temperature of this $\alpha$-amylase was $70^{\circ} \mathrm{C}$, which was higher or similar to that described for other Bacillus $\alpha$-amylases $(4,7,8,13)$. The residual activity of crude $\alpha$-amylase incubated at different temperatures for a period of $2 \mathrm{~h}$ and $24 \mathrm{~h}$ was estimated at optimum temperature. The enzyme was stable for $2 \mathrm{~h}$ at temperatures ranging from $40-50^{\circ} \mathrm{C}$ while at $60^{\circ} \mathrm{C}, 70^{\circ} \mathrm{C}$ and $90^{\circ} \mathrm{C}, 4 \%, 13 \%$ and $38 \%$ of the original activities were lost respectively.

\section{Effect of metal ions}

Because metal ions could be generated from equipment corrosion, specially when subject to acid hydrolysis, the effect of some metal ions at the concentration of $1 \mathrm{mM}$ in the activity of $\alpha$-amylase was investigated. As can be observed in Table 1 , the $\alpha$-amylase did not require any specific ion for catalytic activity. A slight activity inhibition was produced in the activity by $\mathrm{Ca}^{2+}, \mathrm{Mg}^{2+}, \mathrm{Ni}^{2+}, \mathrm{Sr}^{2+}$ and $\mathrm{Mn}^{2+}$, and a stronger inhibitory effect was observed in the presence of $\mathrm{Co}^{2+}, \mathrm{Cu}^{2+}$ and $\mathrm{Ba}^{2+}$. Some amylases are metalloenzymes, containing a

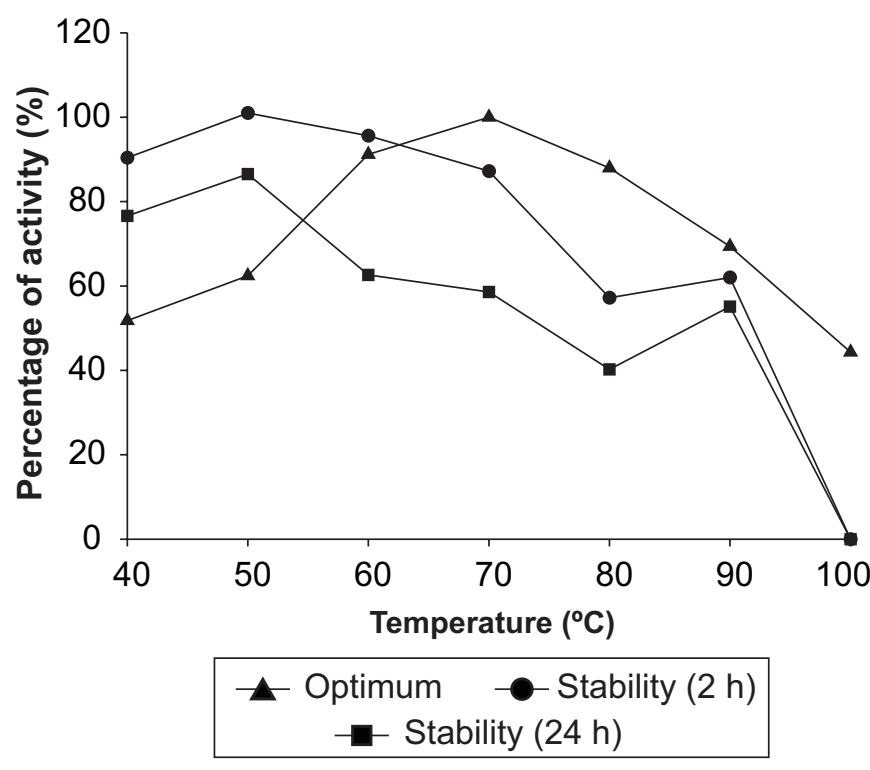

Figure 3. Optimum temperature and stability temperature of $\alpha$-amylase produced by Bacillus sp. strain SMIA-2 grown at $55^{\circ} \mathrm{C}$ for $48 \mathrm{~h}$. Relative activity is expressed as a percentage of the maximum $(100 \%$ of enzyme activity $=78 \mathrm{U} / \mathrm{mL})$.

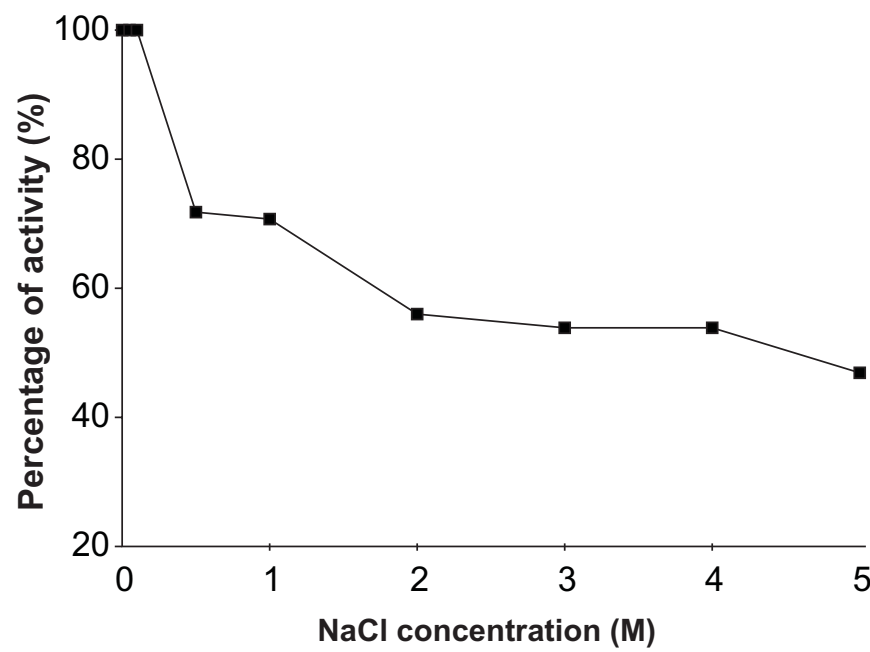

Figure 4. Effect of $\mathrm{NaCl}$ concentration on $\alpha$-amylase produced by Bacillus sp. strain SMIA-2 grown at $55^{\circ} \mathrm{C}$ for $48 \mathrm{~h}$. Relative activity is expressed as a percentage of the maximum (100\% of enzyme activity $=79 \mathrm{U} / \mathrm{mL}$ ).

metal ion for catalytic activity. The inhibition of Bacillus sp. strain SMIA-2 $\alpha$-amylase by $\mathrm{Co}^{2+}, \mathrm{Cu}^{2+}$ and $\mathrm{Ba}^{2+}$ ions could be due to competition between the exogenous cations and the protein-associated cation, resulting in decreased metalloenzyme activity (12). 
Table 1. Effect of different ions on $\alpha$-amylase activity produced by Bacillus sp. strain SMIA-2 grown at $55^{\circ} \mathrm{C}$ during $48 \mathrm{~h}$.

\begin{tabular}{cc}
\hline & \multicolumn{2}{c}{ Percentage of activity (\%) } \\
\cline { 2 - 2 } Ion & $1 \mathrm{mM}$ \\
\hline Control (no addition) & 100 \\
$\mathrm{Ca}^{2+}$ & 89 \\
$\mathrm{Mg}^{2+}$ & 97 \\
$\mathrm{Fe}^{2+}$ & 75 \\
$\mathrm{Fe}^{3+}$ & 59 \\
$\mathrm{Co}^{2+}$ & 26 \\
$\mathrm{Zn}^{2+}$ & 73 \\
$\mathrm{Mn}^{2+}$ & 93 \\
$\mathrm{Hg}^{2+}$ & 45 \\
$\mathrm{Cu}^{2+}$ & 87 \\
$\mathrm{Cs}^{2+}$ & 101 \\
$\mathrm{Ni}^{2+}$ & 90 \\
$\mathrm{Sr}^{2+}$ & 91 \\
$\mathrm{~Pb}^{2+}$ & 101 \\
$\mathrm{Cu}^{2+}$ & 26 \\
$\mathrm{Ba}^{2+}$ & 38 \\
$\mathrm{Ag}^{1+}$ & 88 \\
\hline
\end{tabular}

The percentage of activity is expressed as a percentage of the control $(100 \%$ of enzyme activity $=42 \mathrm{U} / \mathrm{mL})$.

The effects of metal ions on the activity of $\alpha$-amylase in Bacillus sp. strain KSM-1378, a relative of Bacillus firmus, was investigated by Igarashi et al. (7). $\mathrm{Ni}^{2+}, \mathrm{Cd}^{2+}, \mathrm{Zn}^{2+}$, and $\mathrm{Hg}^{2+}$ ions strongly inhibited the enzymatic activity by $82,91,100$, and $100 \%$ respectively. On the other hand, in Bacillus sp. TS$23, \mathrm{Ni}^{2+}$ and $\mathrm{Cd}^{2+}$ slightly inhibited amylase activity.

\section{Salt tolerance test}

This test is important in treatment of effluent with high salinity containing starch or cellulosic residues in pollution control mechanism. The enzyme in $1.0 \mathrm{M}$ and $5 \mathrm{M} \mathrm{NaCl}$ solution retained $70 \%$ and $47 \%$ of the original activity after $24 \mathrm{~h}$ at $4{ }^{\circ} \mathrm{C}$, respectively. The $\alpha$-amylase produced by Bacillus sp. MD 124 (9) was stable in $5 \mathrm{M} \mathrm{NaCl}$ solution and retained $75 \%$ of its original activity after $24 \mathrm{~h}$.

\section{ACKNOWLEDGMENTS}

The authors are highly thankful to the Fundação de Amparo à Pesquisa do Estado do Rio de Janeiro for financial support.

\section{RESUMO}

\section{Produção e propriedades de $\alpha$-amilase de Bacillus sp. termofílico}

A produção de $\alpha$-amilase (1,4- $\alpha$-D-glicano glicanohidrolase, EC 3.2.1.1) por um Bacillus sp cepa SMIA-2 cultivado em meios líquidos contendo amido solúvel, alcançou o máximo em $48 \mathrm{~h}$ com níveis de $57 \mathrm{U} / \mathrm{mL}$. Estudos sobre a caracterização de $\alpha$ amilase revelaram que a temperatura ótima de atividade desta enzima foi $70^{\circ} \mathrm{C}$. A enzima foi estável por $2 \mathrm{~h}$ a $50^{\circ} \mathrm{C}$, enquanto que a $60^{\circ} \mathrm{C}, 70^{\circ} \mathrm{C}$ e $90^{\circ} \mathrm{C}, 4 \%, 13 \%$ e $38 \%$ da atividade original foram perdidas, respectivamente. $\mathrm{O}$ pH ótimo da enzima foi 7,5. Após a incubação da enzima bruta por $24 \mathrm{~h}$ a pH 7,5 observouse um decréscimo em torno de $5 \%$ de sua atividade original. A

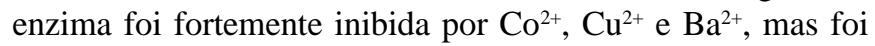
menos afetada por $\mathrm{Ca}^{2+}, \mathrm{Mg}^{2+}, \mathrm{Ni}^{2+}, \mathrm{Sr}^{2+} \mathrm{e} \mathrm{Mn}^{2+}$. Em solução de $\mathrm{NaCl} 1 \mathrm{M}$ e $5 \mathrm{M}$, a enzima reteve $70 \%$ e $47 \%$ da sua atividade original após $24 \mathrm{~h}$ a $4^{\circ} \mathrm{C}$, respectivamente.

Palavras-chave: $\alpha$-amilase, bactéria termofílica, Bacillus sp.

\section{REFERENCES}

1. Adams, M.W.W.; Kelly, R.M. Finding and using thermophilic enzymes. Trends Biotechnol. 16: 329-332, 1998.

2. Becker, P.; Abu-Reesh, I.; Markossian, S. Determination of the kinetic parameters during continuous cultivation of the lipase-producing thermopile Bacillus sp. IHI-91 on olive oil. App. Microbiol. Biotechnol., 48: 184-190, 1997.

3. Beg, Q.K.; Bhushan, B.; Kapoor, M.; Hoondal, G.S. Production and characterization of thermostable xylanase and pectinase from Streptomyces sp. QG-11-3. J. Ind. Microbiol. Biotechnol., 24: 396402, 2000.

4. Bolton, D.J.; Kelly, C.T.; Fogarty, W.M. Purification and characterization of the $\alpha$-amylase of Bacillus flavothermus. Enzy. Microbiol. Technol., 20: 340-343, 1997.

5. Declerck, N.; Machius, M.; Wiegand, G.; Huber, R.; Gaillardin, C. Probing structural determinants specifying high thermostability in Bacillus licheniformis $\alpha$-amylase. J. Mol. Biol., 31: 1041-1057, 2000.

6. Fitter, J.; Heberle, J. Structural equilibrium fluctuations in mesophilic and thermophilic $\alpha$-amylase. Biophys. J., 79: 1629-1636, 2000.

7. Igarashi, K.; Hatada, Y.; Hagihara, H.; Saeki, K.; Takaiwa, M.U.T.; Arai, K.; Ozaki, K.; Kawai, S.; Kobayashi, T.; Ito, S. Enzimatic properties of a novel liquefying $\alpha$-amylase from an alkaliphilic Bacillus isolated and entire nucleotide and amino acid sequences. Appl. Environm. Microbiol., 64: 3282-3289, 1988.

8. Ito, S.; Kobayashi, T.; Ara, K.; Ozaki, K.; Kawai, S.; Hatada, Y. Alkaline detergent enzymes from alkaliphiles: Enzymatic properties, genetics and structure. Extremophiles 2: 185-190, 1998.

9. Jana, M.; Pati, B. Thermostable, salt-tolerant $\alpha$-amylase from Bacillus sp. MD 124. J. Bas. Microbiol., 37: 323-326, 1997.

10. Ladenstein, R.; Antranikian, G. Proteins from hyperthermophiles: Stability and enzymatic catalysis close to the boiling point of water. Adv. Biochem. Eng. Biotechnol., 61: 37-85, 1998.

11. Lee, D.W.; Koh, Y.S.; Kim, K.J.; Kim, B.C.; Choi, H.J.; Kim, D.S.; Suhartono, M.T.; Pyun, Y.R. Isolation and characterization of a thermophilic lipase from Bacillus thermoleovorans ID-1. FEMS Microbiol. Lett., 179: 393-400, 1999.

12. Lévêque, E.; Janecek, S.; Haye, B.; Belarbi, A. Thermophilic archaeal amylolytic enzymes. Enzy. Microbiol. Technol., 26: 3-14, 2000.

13. Lin, L.L.; Chyau, C.C.; Hsu, W.H. Production and properties of a raw-starch-degrading amylase from thermophilic and alkaliphilic Bacillus sp. TS-23. Biotechnol. Appl. Biochem., 28: 61-68, 1998.

14. Maciver, B.; McHale, R.H.; Saul, D.J.; Bergquist, P.L. Cloning and sequencing of a serine proteinase gene from a thermophilic Bacillus species and its expression in Escherichia coli. Appl. Environ. Microbiol., 60: 3981-3988, 1994. 
15. Marchal, L.M.; Jonkers, J.; Franke, G.T.; de Gooijer, C.D.; Tramper, $J$. The effect of process conditions on the $\alpha$-amylolytic hydrolysis of amylopectin potato starch: An experimental design approach. Biotechnol. Bioeng., 62: 348-357, 1999.

16. McMahon, H.E.M.; Kelly, C.T.; Fogarty, W.M. Thermostability of three $\alpha$-amylases of Streptomyces sp. IMD 2679. J. Ind. Microbiol. Biotechnol., 22: 96-99, 1999.

17. Miller, G.L. Use of dinitrosalicylic acid reagent for determination of reducing sugars. Anal. Chem., 3: 426-428, 1959.

18. Niehaus, F.; Bertoldo, C.; Kahler, M.; Antranikian, G. Extremophiles as a source of novel enzymes for industrial application. Appl. Microbiol. Biotechnol., 51: 711-729, 1999.

19. Nunes, A.S. Influência da temperatura sobre os requerimentos nutricionais de um Bacillus sp. termofílico. Tese (Mestrado em Produção Vegetal) - Campos dos Goytacazes - RJ, Universidade Estadual do Norte Fluminense - UENF, 63p. 2000.
20. Roy, I.; Sastry, M.S.R.; Johri, B.N.; Gupta, M.N. Purification of $\alpha$-amylase isoenzymes from Scytalidium thermophilum on a fluidized bed of alginate beads followed by concanavalin A agarose column chromatography. Protein Expr. Purif., 20: 162-168, 2000.

21. Sonnleitner, B.; Fiechter, A. Advantages of using thermophiles in biotechnological processes: expectations and reality. Trends Biotechnol., 1: 74-80, 1983

22. Suresh, C.; Dubey, A.K.; Srikanta, S.; Kumar, S.U.; Karanth, N.G. Characterisation of a starch-hydrolysing enzyme of Aspergillus niger. Appl. Microbiol. Biotechnol., 51: 673-675, 1999.

23. Touzel, J.P.; O'Donohue, M.; Debeire, P.; Samain, E.; Breton, C. Thermobacillus xylanilyticus gen. Nov., sp. nov., a new aerobic thermophilic xylan-degrading bacterium isolated from farm soil. Int. J. Syst. Evol. Microbiol., 50: 315-320, 2000.

24. Zeikus, J.G.; Vieille, C.; Savchenko, A. Thermozymes: Biotechnology and structure-function relationship. Extremophiles, 1: 2-13, 1998 